\title{
LEAF AREA OF COMMON BEAN GENOTYPES DURING EARLY POD FILLING AS RELATED TO PLANT ADAPTATION TO LIMITED PHOSPHORUS SUPPLY ${ }^{(1)}$
}

\author{
Roberto Santos Trindade ${ }^{(2)}$, Adelson Paulo Araújo ${ }^{(3)}$ \& Marcelo Grandi Teixeira $^{(4)}$
}

\begin{abstract}
SUMMARY
Low phosphorus supply markedly limits leaf growth and genotypes able to maintain adequate leaf area at low $P$ could adapt better to limited-P conditions. This work aimed to investigate the relationship between leaf area production of common bean (Phaseolus vulgaris) genotypes during early pod filling and plant adaptation to limited $P$ supply. Twenty-four genotypes, comprised of the four growth habits in the species and two weedy accessions, were grown at two $\mathrm{P}$ level applied to the soil $\left(20\right.$ and $\left.80 \mathrm{mg} \mathrm{kg}^{-1}\right)$ in $4 \mathrm{~kg}$ pots and harvested at two growth stages (pod setting and early pod filling). High P level markedly increased the leaf number and leaf size (leaf area per leaf), slightly increased specific leaf area but did not affect the net assimilation rate. At low $P$ level most genotypic variation for plant dry mass was associated with leaf size, whereas at high $P$ level this variation was associated primarily with the number of leaves and secondarily with leaf size, specific leaf area playing a minor role at both $P$ level. Determinate bush genotypes presented a smaller leaf area, fewer but larger leaves with higher specific leaf area and lower net assimilation rate. Climbing genotypes showed numerous leaves, smaller and thicker leaves with a higher net assimilation rate. Indeterminate bush and indeterminate prostrate genotypes presented the highest leaf area, achieved through intermediate leaf number, leaf size and specific leaf area. The latter groups were better adapted to limited P. It is concluded that improved growth at low $\mathbf{P}$ during early pod filling was associated with common bean genotypes able to maintain leaf expansion through leaves with greater individual leaf area.
\end{abstract}

Index terms: genetic variability, growth habit, Phaseolus vulgaris, phosphorus efficiency, plant growth analysis.

\footnotetext{
(1) Part of the Master degree Dissertation of the first author, submitted to the Post Graduation Program of Soil Science, Universidade Federal Rural do Rio de Janeiro - UFRRJ. Received for publication in April 2009 and aproved in October 2009.

${ }^{(2)}$ Student of Doctorate in Genetic and Plant Breeding, Universidade Estadual do Norte Fluminense - UENF. Av. Alberto Lamego 2000, CEP 28013-602 Campos dos Goytacazes (RJ). E-mail: roberto_s_trindade@yahoo.com.br

(3) Departamento de Solos, Universidade Federal Rural do Rio de Janeiro - UFRRJ. CEP 23890-000 Seropédica (RJ). E-mail: aparaujo@ufrrj.br

(4) Embrapa Agrobiologia, CEP 23890-000 Seropédica (RJ). E-mail: grandi@cnpab.embrapa.br
} 


\title{
RESUMO: ÁREA FOLIAR DE GENÓTIPOS DE FEIJOEIRO NO INÍCIO DE ENCHIMENTO DE VAGENS E SUA RELAÇÃO COM A ADAPTAÇÃO VEGETAL AO SUPRIMENTO LIMITADO DE FÓSFORO
}

\begin{abstract}
O baixo suprimento de P limita acentuadamente o crescimento foliar, e genótipos capazes de manter adequada área foliar sob baixo P podem adaptar-se melhor a condições de limitação do nutriente. Este trabalho teve por objetivo investigar as relações entre a produção de área foliar de genótipos de feijoeiro (Phaseolus vulgaris) no início de enchimento de vagens e a adaptação vegetal ao baixo suprimento de P. Em vasos com $4 \mathrm{~kg}$ de solo, 24 genótipos de feijoeiro, compreendendo os quatro hábitos de crescimento e dois genótipos silvestres, foram crescidos em duas doses de P aplicado (20 e $80 \mathrm{mg} \mathrm{kg}^{-1}$ ) e coletados na emissão de vagens e no início de enchimento destas. A maior dose de Paumentou acentuadamente o número de folhas e a área foliar por folha e ligeiramente a área foliar específica, mas não alterou a taxa de assimilação líquida. Em baixo $P$, a variação genotípica na biomassa foi associada principalmente ao tamanho da folha, enquanto em alto $P$ esta variação esteve associada primeiramente ao número de folhas e secundariamente ao tamanho da folha, tendo a área foliar específica menor importância. Genótipos de hábito determinado apresentaram menor área foliar, folhas maiores e menos numerosas, com maior área foliar específica e menor taxa de assimilação líquida. Plantas de hábito trepador mostraram folhas numerosas, menores e espessas, com maior taxa de assimilação líquida. Genótipos de hábito indeterminado ereto ou prostrado tiveram maior área foliar-obtida por meio de valores intermediários de número de folhas, área foliar por folha e área foliar específica - e mostraram-se mais bem adaptados ao baixo suprimento de P. Conclui-se que o maior crescimento sob suprimento limitado de $P$ durante o início de enchimento de vagens esteve associado a genótipos de feijoeiro capazes de manter a expansão foliar por meio de folhas de maior tamanho.
\end{abstract}

Termos de indexação: análise de crescimento vegetal, eficiência de fósforo, hábito de crescimento, Phaseolus vulgaris, variabilidade genética.

\section{INTRODUCTION}

Leaf area is an important physiological component of crop yield, being itself a complex character. Genotypic differences in yield of many crops are mainly associated with variations in leaf area, since genotypic differences in photosynthetic activity per unit leaf area are inconsistent and generally non-significant (Wallace et al., 1972). Increased grain yield per land area achieved across the $20^{\text {th }}$ century was mainly associated to extended photosynthesis per unit land area, obtained by increasing the duration of crop period and the amount of light intercepted by the canopy, rather than by enhanced photosynthesis per unit leaf area (Richards, 2000). Leaf morphology within a canopy usually reflects a tradeoff between photosynthesis per unit leaf area and light interception per leaf; thicker leaves allow greater photosynthetic apparatus per unit leaf area, while larger and thinner leaves can intercept more light (White \& Montes-R., 2005). A higher specific leaf area (the ratio between leaf area and leaf dry mass) can compensate the resultant lower photosynthesis per unit leaf area through greater light interception early in crop development (Richards, 2000).

The genus Phaseolus has evolved in America, and patterns of seed protein indicate two primary areas of domestication of $P$. vulgaris: one in Mesoamerica leading to small-seeded cultivars and the other in the Andes giving rise to large-seeded cultivars (Gepts et al., 1986). Further analyses of chloroplast data, isozymes and DNA polymorphism support the independent domestication of the common bean in Mesoamerican and Andean regions (Chacón et al., 2005). Leaf photosynthetic characteristics also distinguish these two gene pools: Andean accessions have a higher specific leaf area, lower carbon exchange rate and lower stomatal conductance, as compared to Mesoamerican accessions (González et al., 1995; Sexton et al., 1997). Such geographical origins are related to the yield potential, since Mesoamerican lines usually present higher grain yields than those of the Andes (Sexton et al., 1994). Cultivated germplasm of the common bean is also classified into four growth habits based on shoot architecture and degree of determinacy, as determinate bush, indeterminate bush, indeterminate prostrate, and indeterminate climbing (Laing et al., 1984). Such classification supports breeding efforts to improve plant adaptation to diverse environments and cropping systems under which beans are grown (Graham \& Ranalli, 1997; Singh, 2001).

Phosphorus deficiency strongly reduces leaf area of bean plants, mainly by reducing the number of 
leaves through effects on branching and relative leaf appearance rate, and to a lesser extent by reducing individual leaf expansion (Lynch et al., 1991). On the other hand, $\mathrm{P}$ deficiency only slightly inhibits photosynthetic rates in bean leaves, since modifications of photosynthetic metabolism under limited $\mathrm{P}$ supply can enhance $\mathrm{P}$ recirculation to improve plant adaptation to low P (Kondracka \& Rychter, 1997). However, $\mathrm{P}$ foliar sprays increased net $\mathrm{CO}_{2}$ assimilation in bean leaves under a water deficit (Santos et al., 2004). Indeed, the intensity and timing of the $\mathrm{P}$ stress imposed to experimental plants must be considered in order to understand contradictory effects of $\mathrm{P}$ limitation on leaf growth and photosynthesis (Rodríguez et al., 1998). Richards (2000) suggested that genetic variation in leaf area growth or leaf photosynthesis may be masked under favorable nutrient conditions where breeding trials of crop plants are usually conducted, but such variation shall assume importance for plant adaptation to limiting-nutrient conditions.

The comprehension of the integrated leaf lifespan seems more relevant to crop performance than the analysis solely of instantaneous leaf traits (Lynch \& Rodriguez H., 1994). Indeed, the yield of a common bean cultivar is more closely related to the leaf area duration, which integrates the leaf area over time, than with instantaneous leaf area (Wallace et al., 1972; Laing et al., 1984; Stone \& Pereira, 1994; Lima et al., 2005). Maximal leaf area was observed at early pod filling in six field-grown common bean cultivars (Lima et al., 2005), and the continuous growth and nutrient acquisition during pod filling seems relevant for higher grain yield of common bean crop (Araújo \& Teixeira, 2008). The translocation of nutrients to seeds may limit the late-season photosynthesis of the canopy of the common bean crop (Lynch \& Rodriguez H., 1994), and bean germplasm able to maintain the leaf growth during pod-filling at limited $\mathrm{P}$ supply could serve as a source of adaptation to low $\mathrm{P}$ availability conditions prevalent in tropical soils. Therefore, one experiment was carried out to investigate the relationship between the production of the leaf area of common bean genotypes at early pod filling and the adaptation of plant growth to a limited $\mathrm{P}$ supply.

\section{MATERIAL AND METHODS}

The experiment was carried out at the National Research Center in Agrobiology (Embrapa Agrobiologia, Seropédica, Brazil), from May to July 2005 , in a $24 \times 2 \times 2$ factorial block design with four replicates. Twenty four common bean genotypes were grown at two levels of applied P (20 and $80 \mathrm{mg} \mathrm{kg}^{-1}$ of P) and harvested at two growth stages: pod setting (at least one pod with $2 \mathrm{~cm}$ length) of each genotype, and early pod filling (11 days after), at dates presented in Table 1. The 24 genotypes represented the four growth habits in Phaseolus vulgaris (Table 1), comprising 3 commercial cultivars of habit I, two landraces of habit I of Southern Brazil (Pop 59 and Pop 71), nine commercial cultivars of habit II, six commercial cultivars of habit III, two lines of habit IV from the Brazilian Breeding Program (CF 840694 and CF 840704), and two Mesoamerican weedy genotypes of habit IV previously evaluated by Araújo et al. (1998) (G 12896 and G 12930). Genotypes with similar growth cycles were employed to avoid confounding the effects of growth habit with growth duration. Seeds were available in the germplasm collection of Embrapa Agrobiologia.

The substrate was a 6 -mm sieved sandy loam soil (Ap horizon of Haplustult soil), originally with $2 \mathrm{mg} \mathrm{dm}^{-3}$ of available $\mathrm{P}$ (Mehlich-1), $18 \mathrm{mmol}_{\mathrm{c}} \mathrm{dm}^{-3}$ of $\mathrm{Ca}+\mathrm{Mg}, 4 \mathrm{mmol}_{\mathrm{c}} \mathrm{dm}^{-3}$ of $\mathrm{Al}$, water $\mathrm{pH} 5.0$, and $9.0 \mathrm{~g} \mathrm{~kg}^{-1}$ of organic C. The soil was placed into $4 \mathrm{~kg}$ pots and limed with $500 \mathrm{mg} \mathrm{kg}^{-1}$ of $\mathrm{CaCO}_{3}$. Ten days later, the following nutrients were applied diluted in water (in mg kg-1 of soil): $10 \mathrm{Mg}$ as $\mathrm{MgSO}_{4} \cdot 7 \mathrm{H}_{2} \mathrm{O}, 2$ $\mathrm{Cu}$ as $\mathrm{CuSO}_{4} .5 \mathrm{H}_{2} \mathrm{O}, 1 \mathrm{Zn}$ as $\mathrm{ZnSO}_{4} .7 \mathrm{H}_{2} \mathrm{O}, 0.1 \mathrm{~B}$ as $\mathrm{H}_{3} \mathrm{BO}_{3}, 0.2 \mathrm{Mo}$ as $\mathrm{Na}_{2} \mathrm{MoO}_{4} \cdot 2 \mathrm{H}_{2} \mathrm{O}$, and 20 and $80 \mathrm{P}$ as $\mathrm{KH}_{2} \mathrm{PO}_{4}$ at low and high $\mathrm{P}$ level, respectively. Pots of low $\mathrm{P}$ level received $75 \mathrm{mg} \mathrm{kg}^{-1}$ of $\mathrm{K}$ as $\mathrm{KCl}$ to uniform the K supply. The substrate of each pot was then homogenized. On the sowing date, the soil presented water $\mathrm{pH} 5.9,36 \mathrm{mmol}_{\mathrm{c}} \mathrm{dm}^{-3}$ of $\mathrm{Ca}+\mathrm{Mg}$, $0 \mathrm{mmol}_{\mathrm{c}} \mathrm{dm}^{-3}$ of Al, and 12 and $52 \mathrm{mg} \mathrm{dm}^{-3}$ of available $\mathrm{P}$ at levels of 20 and $80 \mathrm{mg} \mathrm{kg}^{-1}$ of $\mathrm{P}$, respectively. The low and high $\mathrm{P}$ level are assumed to establish limited and adequate $\mathrm{P}$ supplies, respectively, for bean plants grown in pots with this kind of soil (Araújo et al., 1998).

Seeds were inoculated with liquid inoculant containing the strains CIAT 899 and PRF 81 of Rhizobium tropici, and two plants were grown per pot after thinning. Pots were placed in the open air, above tiles on a greensward. Plants were irrigated daily. Twenty five days after emergence $80 \mathrm{mg} \mathrm{N}$ per pot was applied as $(\mathrm{NH})_{4} \mathrm{SO}_{4}$. Plants of indeterminate growth habit were staked. During the course of the experiment, mean temperature ranged from 18 to $23{ }^{\circ} \mathrm{C}$ and mean relative humidity was $65 \%$. At harvest, expanded trifoliates (including petioles) of each pot were detached and counted, and leaf area was measured photoelectrically (Li-Cor 3100 Area Meter). Roots and nodules were recovered by washing the soil through a sieve. Leaves (including petioles), stems, pods, roots, and nodules were separately oven dried and weighed. Specific leaf area was calculated as the ratio between the whole leaf area and leaf dry mass of each plant.

The analysis of variance was performed as a twofactor design in each time of harvest, evaluating the effects of genotype, $\mathrm{P}$ level and their interaction. The least significant difference between genotypes was estimated by the Tukey test. Genotypes were also grouped according to the growth habit, and means of 
Table 1. Characteristics of the 24 genotypes of common bean (Phaseolus vulgaris) evaluated

\begin{tabular}{|c|c|c|c|c|c|}
\hline \multirow{2}{*}{ Number } & \multirow{2}{*}{ Name $^{(1)}$} & \multirow{2}{*}{ Growth habit ${ }^{(2)}$} & \multirow{2}{*}{ Seed mass } & \multicolumn{2}{|c|}{ Harvest (days after emergence) } \\
\hline & & & & Pod setting & Early pod filling \\
\hline & & & $\mathrm{mg}$ & & \\
\hline 1 & Constanza & I & 559 & 32 & 43 \\
\hline 2 & Goiano Precoce & $\mathrm{I}$ & 366 & 31 & 42 \\
\hline 3 & Iraí & I & 435 & 31 & 42 \\
\hline 4 & Pop 59 & I & 525 & 33 & 44 \\
\hline 5 & Pop 71 & I & 449 & 30 & 41 \\
\hline 6 & BAT 477 & II & 205 & 39 & 50 \\
\hline 7 & Guapo Brilhante & II & 209 & 38 & 49 \\
\hline 8 & ICA Pijao & II & 229 & 39 & 50 \\
\hline 9 & Jalo EEP 558 & II & 533 & 34 & 45 \\
\hline 10 & Manteigão PC & II & 511 & 31 & 42 \\
\hline 11 & Rico 23 & II & 219 & 34 & 45 \\
\hline 12 & Rio Tibagi & II & 208 & 38 & 49 \\
\hline 13 & Safira & II & 222 & 36 & 47 \\
\hline 14 & Xodó & II & 241 & 34 & 45 \\
\hline 15 & Aporé & III & 236 & 39 & 50 \\
\hline 16 & Capixaba Precoce & III & 244 & 31 & 42 \\
\hline 17 & Carioca & III & 254 & 38 & 49 \\
\hline 18 & Flor de Mayo & III & 271 & 34 & 45 \\
\hline 19 & Ouro Negro & III & 289 & 35 & 46 \\
\hline 20 & Puebla 152 & III & 287 & 38 & 49 \\
\hline 21 & CF 840694 & IV & 271 & 38 & 49 \\
\hline 22 & CF 840704 & IV & 282 & 38 & 49 \\
\hline 23 & G 12896 & IV & 133 & 35 & 46 \\
\hline 24 & G 12930 & IV & 143 & 35 & 46 \\
\hline
\end{tabular}

(1) Genotypes: Pop 59 and Pop 71 are landraces of Southern Brazil; CF 840694 and CF 840704 are lines originated from the Brazilian Breeding Program; G 12896 and G 12930 are weedy genotypes; the others are commercial cultivars. ${ }^{(2)}$ Growth habit: I determinate bush, II indeterminate bush, III indeterminate prostrate, IV indeterminate climbing.

each growth habit were compared by the Tukey test taking into account the different number of genotypes in each group. Simple correlations between traits were obtained; structural regressions considering random independent variables (Neter et al., 1990) were also performed but they did not improve data interpretation. The following growth rates were calculated: $\mathrm{AGR}=\left(\mathrm{M}_{2}-\mathrm{M}_{1}\right) /\left(\mathrm{T}_{2}-\mathrm{T}_{1}\right), \mathrm{RGR}=\left(\mathrm{lnM}_{2}-\right.$ $\left.\ln \mathrm{M}_{1}\right) /\left(\mathrm{T}_{2}-\mathrm{T}_{1}\right), \mathrm{NAR}=\left[\left(\mathrm{M}_{2}-\mathrm{M}_{1}\right) /\left(\mathrm{A}_{2}-\mathrm{A}_{1}\right)\right]\left[\left(\ln \mathrm{A}_{2}-\ln \mathrm{A}_{1}\right) /\right.$ $\left(\mathrm{T}_{2}-\mathrm{T}_{1}\right)$ ], where AGR is the absolute growth rate (in $\mathrm{mg} \mathrm{d}^{-1}$ ), RGR the relative growth rate (in $\mathrm{mg} \mathrm{g} \mathrm{d}^{-1}$ ), NAR the net assimilation rate (in $\mathrm{g} \mathrm{m}^{-2} \mathrm{~d}^{-1}$ ), M the total dry mass, A the leaf area, and $\mathrm{T}$ the time (in days after emergence), at each time of harvest. One rate value was calculated for each experimental block, providing four replicates of the rates that allowed the statistical analysis.

An empirical model was built to investigate the relationship between plant traits, considering plant biomass as the product of leaf appearance, leaf extension, leaf thickness, and the proportion of biomass allocated to leaves, as follows:

or

$$
\mathrm{M}_{\mathrm{T}}=\mathrm{N}_{\mathrm{L}} \times \mathrm{A}_{\mathrm{L}} / \mathrm{N}_{\mathrm{L}} \times \mathrm{M}_{\mathrm{L}} / \mathrm{A}_{\mathrm{L}} \times \mathrm{M}_{\mathrm{T}} / \mathrm{M}_{\mathrm{L}}
$$

$$
\ln \mathrm{M}_{\mathrm{T}}=\ln \mathrm{N}_{\mathrm{L}}+\ln \mathrm{A}_{\mathrm{L}} / \mathrm{N}_{\mathrm{L}}-\ln \mathrm{SLA}-\ln \mathrm{LMR}
$$

where $\mathrm{M}_{\mathrm{T}}$ is the total plant dry mass (in g/plant), $\mathrm{N}_{\mathrm{L}}$ the number of leaves per plant, $A_{L}$ the leaf area per plant, $\mathrm{M}_{\mathrm{L}}$ the leaf dry mass per plant, $\mathrm{A}_{\mathrm{L}} / \mathrm{N}_{\mathrm{L}}$ the leaf size (leaf area per leaf, in $\mathrm{cm}^{2}$ ), SLA the specific leaf area (leaf area per leaf dry mass, in $\mathrm{cm}^{2} \mathrm{~g}^{-1}$ ), and LMR the leaf mass ratio (the proportion of total plant dry mass allocated to leaves, in $\mathrm{g} \mathrm{g}^{-1}$ ). Stepwise multiple regressions for each $\mathrm{P}$ level and each time of harvest were used to isolate the effect of each component as included in the model (Neter et al., 1990).

\section{RESULTS}

The low P level applied to the soil reduced the total dry mass (the sum of shoot, root and nodule dry mass) and leaf area of all genotypes at pod setting and early pod filling growth stages (Figure 1). Bean genotypes differed in total dry mass and leaf area at both $\mathrm{P}$ level at early pod filling and at high $\mathrm{P}$ level at pod setting. However, at low $\mathrm{P}$ level at pod setting three had no significant differences between genotypes (Figure 1). This confirmed that the identification of bean lines tolerant to low $\mathrm{P}$ supply depends on the growth stage in which the evaluation is performed (Araújo \& Teixeira, 2000). The cultivars Constanza, ICA Pijao 

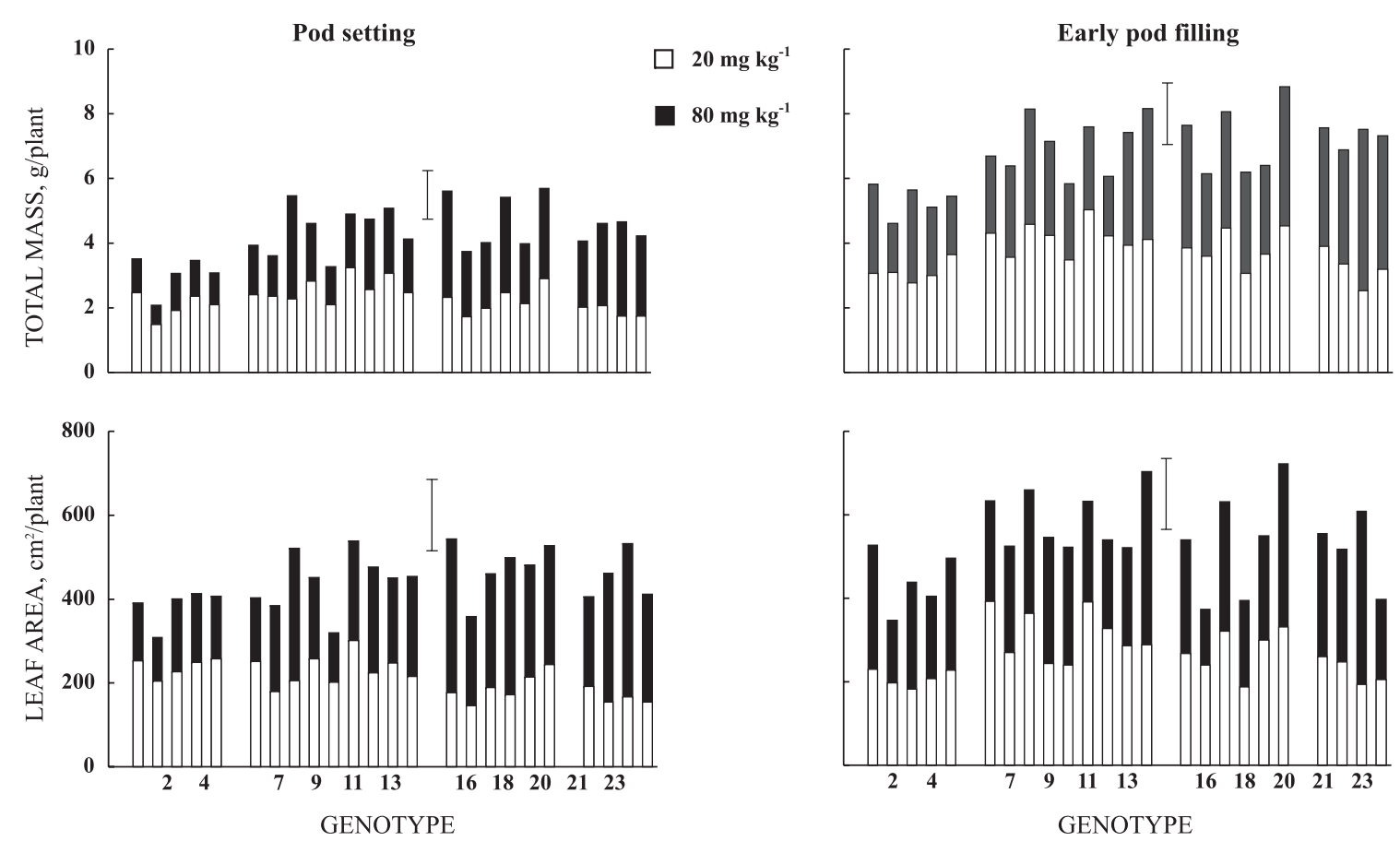

Figure 1. Total dry mass (shoot + root) and leaf area of 24 common bean genotypes grown at $P$ level applied to the soil of $20(\square)$ and 80 (口) $\mathrm{mg} \mathrm{kg}^{-1}$ of $\mathrm{P}$ at two growth stages (pod setting and early pod filling); means of four replicates. Vertical bars represent the least significant difference by the Tukey test $5 \%$, and compare genotypes within each $\mathrm{P}$ level; names of the genotypes are in Table 1.

and Puebla 152 (numbers 1, 8 and 20 in figure 1, respectively) yielded the highest biomass at both $\mathrm{P}$ level and both harvests within the growth habits I, II and III, respectively. At low P level, cultivars BAT 477, ICA Pijao and Rico 23 (numbers 6, 8 and 11 in figure 1, respectively) had the highest leaf area at early pod filling. The cultivars Rico 23 and Puebla 152 increased sharply the leaf area between pod setting and early pod filling, presenting the highest leaf area at high $\mathrm{P}$ level at the second harvest (Figure 1).

Averaged across genotypes, the high $\mathrm{P}$ level increased the total dry mass by 97 and $102 \%$, the leaf area by 109 and $100 \%$, the number of leaves by 68 and $47 \%$, and the leaf area per leaf by 29 and $34 \%$, at pod setting and early pod filling, respectively (Table 2). At both growth stages, specific leaf area was slightly increased at high P level, but part of this increase was ascribed to the intense production of young leaves with a higher specific leaf area as the $\mathrm{P}$ supply was raised. At pod setting, genotypes of habit I produced lower shoot mass than the others at high P level. At early pod filling, genotypes of group II had more shoot mass than groups I and IV at low P level, but at high P level group IV was superior. Groups I and IV presented lower root dry mass than groups II and III at both $\mathrm{P}$ level and both sampling dates, group II rooting better (Table 2 ).

At pod setting, genotypes of group I produced less leaf area at high P level, while at early pod filling group II had a higher leaf area than groups I and IV at both P level (Table 2). Genotypes of group IV had the highest number of leaves, and groups II and III more leaves than group I, at both P level and both harvests. At pod setting, genotypes of group I presented the largest leaves (as expressed by the leaf area per leaf), and at early pod filling groups I and II had the largest leaves. Groups III and IV always had smaller leaves (Table 2). At both P level and both harvests, genotypes of habit I presented the highest specific leaf area, and those of habit IV the lowest specific leaf area (Table 2).

Absolute growth rate between pod setting and early pod filling, averaged across genotypes, increased as $\mathrm{P}$ level was raised, but the relative growth rate was unaffected by added P (Table 3). At high P level, genotypes of group IV had higher absolute growth rates whereas group I higher relative growth rates. Soil P supply did not affect the net assimilation rate (NAR) estimated between pod setting and early pod filling, as observed by Araújo \& Teixeira (2000). At low P level, genotypes of groups III and IV showed higher NAR than genotypes of group I (Table 3), suggesting that genotypic differences in photosynthetic activity under a limited $\mathrm{P}$ supply can contribute to the efficiency of nutrient utilization (Araújo \& Teixeira, 2000). Correlations between NAR and leaf traits were hard to establish. Nonetheless, the genotypes with higher SLA, such as group I, displayed lower NAR at low P level (Tables 2 and 3). 
Table 2. Shoot dry mass, root (+ nodule) dry mass, leaf area, number of leaves, leaf area per leaf, and specific leaf area of 24 common bean genotypes grouped by growth habit, grown at two $P$ level applied to the soil (20 and $80 \mathrm{mg} \mathrm{kg}^{-1}$ of $\mathrm{P}$ ) at two growth stages (pod setting and early pod filling)

\begin{tabular}{|c|c|c|c|c|c|c|c|c|}
\hline \multirow{2}{*}{$\begin{array}{c}\text { Growth } \\
\text { habit }\end{array}$} & \multicolumn{2}{|c|}{ Pod setting } & \multicolumn{2}{|c|}{ Early pod filling } & \multicolumn{2}{|c|}{ Pod setting } & \multicolumn{2}{|c|}{ Early pod filling } \\
\hline & $20 \mathrm{mg} \mathrm{kg}^{-1}$ & $80 \mathrm{mg} \mathrm{kg}^{-1}$ & $20 \mathrm{mg} \mathrm{kg}^{-1}$ & $80 \mathrm{mg} \mathrm{kg}^{-1}$ & $20 \mathrm{mg} \mathrm{kg}^{-1}$ & $80 \mathrm{mg} \mathrm{kg}^{-1}$ & $20 \mathrm{mg} \mathrm{kg}^{-1}$ & $80 \mathrm{mg} \mathrm{kg}^{-1}$ \\
\hline & \multicolumn{4}{|c|}{ Shoot dry mass (g/plant) } & \multicolumn{4}{|c|}{ Root dry mass (g/plant) } \\
\hline $\mathrm{I}$ & $1.34 \mathrm{a}$ & $2.05 \mathrm{~b}$ & $2.28 \mathrm{c}$ & $4.24 \mathrm{c}$ & $0.73 \mathrm{ab}$ & $0.99 \mathrm{~b}$ & $0.83 \mathrm{c}$ & $1.09 \mathrm{c}$ \\
\hline II & $1.75 \mathrm{a}$ & $3.15 \mathrm{a}$ & $2.90 \mathrm{a}$ & $5.45 \mathrm{~b}$ & $0.84 \mathrm{a}$ & $1.27 \mathrm{a}$ & $1.27 \mathrm{a}$ & $1.59 \mathrm{a}$ \\
\hline III & $1.60 \mathrm{a}$ & $3.57 \mathrm{a}$ & $2.76 \mathrm{ab}$ & $5.72 \mathrm{ab}$ & $0.66 \mathrm{bc}$ & $1.17 \mathrm{a}$ & $1.10 \mathrm{~b}$ & $1.49 \mathrm{a}$ \\
\hline IV & $1.33 \mathrm{a}$ & $3.47 \mathrm{a}$ & $2.46 \mathrm{bc}$ & $6.08 \mathrm{a}$ & $0.56 \mathrm{c}$ & $0.92 \mathrm{~b}$ & $0.79 \mathrm{c}$ & $1.25 \mathrm{~b}$ \\
\hline Mean & 1.56 & 3.08 & 2.66 & 5.37 & 0.72 & 1.13 & 1.05 & 1.40 \\
\hline \multicolumn{5}{|c|}{ Leaf area $\left(\mathrm{cm}^{2} /\right.$ plant $)$} & \multicolumn{4}{|c|}{ Number of leaves (plant ${ }^{-1}$ ) } \\
\hline I & $238 \mathrm{a}$ & $384 \mathrm{~b}$ & $209 \mathrm{c}$ & $443 \mathrm{c}$ & $6.0 \mathrm{~b}$ & $7.9 \mathrm{~d}$ & $6.8 \mathrm{c}$ & $9.8 \mathrm{c}$ \\
\hline II & $231 \mathrm{a}$ & $444 \mathrm{a}$ & $311 \mathrm{a}$ & $587 \mathrm{a}$ & $7.0 \mathrm{ab}$ & $10.8 \mathrm{c}$ & $10.0 \mathrm{~b}$ & $14.5 \mathrm{~b}$ \\
\hline III & $190 \mathrm{a}$ & $478 \mathrm{a}$ & $274 \mathrm{ab}$ & $535 \mathrm{ab}$ & $7.4 \mathrm{a}$ & $13.1 \mathrm{~b}$ & $10.8 \mathrm{~b}$ & $15.5 \mathrm{~b}$ \\
\hline IV & $176 \mathrm{a}$ & $453 \mathrm{a}$ & $226 \mathrm{bc}$ & $520 \mathrm{~b}$ & $8.2 \mathrm{a}$ & $17.4 \mathrm{a}$ & $12.3 \mathrm{a}$ & $19.6 \mathrm{a}$ \\
\hline Mean & 211 & 442 & 267 & 533 & 7.1 & 11.9 & 9.9 & 14.6 \\
\hline \multicolumn{5}{|c|}{ Leaf area per leaf $\left(\mathrm{cm}^{2}\right)$} & \multicolumn{4}{|c|}{ Specific leaf area $\left(\mathrm{cm}^{2} \mathrm{~g}^{-1}\right)$} \\
\hline $\mathrm{I}$ & $41 \mathrm{a}$ & $50 \mathrm{a}$ & $32 \mathrm{a}$ & $45 \mathrm{a}$ & $273 \mathrm{a}$ & $279 \mathrm{a}$ & $216 \mathrm{a}$ & $229 \mathrm{a}$ \\
\hline II & $33 \mathrm{~b}$ & $42 \mathrm{~b}$ & $32 \mathrm{a}$ & $42 \mathrm{a}$ & $195 \mathrm{~b}$ & $206 \mathrm{~b}$ & $184 \mathrm{~b}$ & $195 \mathrm{~b}$ \\
\hline III & $28 \mathrm{c}$ & $39 \mathrm{~b}$ & $27 \mathrm{~b}$ & $36 \mathrm{~b}$ & $186 \mathrm{bc}$ & $202 \mathrm{~b}$ & $176 \mathrm{~b}$ & $186 \mathrm{bc}$ \\
\hline IV & $20 \mathrm{~d}$ & $27 \mathrm{c}$ & $19 \mathrm{c}$ & $27 \mathrm{c}$ & $174 \mathrm{c}$ & $182 \mathrm{c}$ & $157 \mathrm{c}$ & $175 \mathrm{c}$ \\
\hline Mean & 31 & 40 & 29 & 39 & 206 & 216 & 184 & 197 \\
\hline
\end{tabular}

Means followed by the same letter within a column do not differ by Tukey test $5 \%$.

Table 3. Absolute growth rate, relative growth rate, and net assimilation rate of 24 common bean genotypes grouped by growth habit, grown at two $P$ level applied to the soil ( 20 and $80 \mathrm{mg} \mathrm{kg}^{-1} \mathrm{of} P$ ), at the $11 \mathrm{day}$ interval between pod setting and early pod filling

\begin{tabular}{|c|c|c|c|c|c|c|}
\hline \multirow{2}{*}{ Growth habit } & \multicolumn{2}{|c|}{ Absolute growth rate } & \multicolumn{2}{|c|}{ Relative growth rate } & \multicolumn{2}{|c|}{ Net assimilation rate } \\
\hline & $20 \mathrm{mg} \mathrm{kg}^{-1}$ & $80 \mathrm{mg} \mathrm{kg}^{-1}$ & $20 \mathrm{mg} \mathrm{kg}^{-1}$ & $80 \mathrm{mg} \mathrm{kg}^{-1}$ & $20 \mathrm{mg} \mathrm{kg}^{-1}$ & $80 \mathrm{mg} \mathrm{kg}^{-1}$ \\
\hline & \multicolumn{2}{|c|}{$\ldots \mathrm{mg} \mathrm{d}^{-1}$} & \multicolumn{2}{|c|}{$\mathrm{mg} \mathrm{g}^{-1} \mathrm{~d}^{-1}$} & \multicolumn{2}{|c|}{$\mathrm{g} \mathrm{m}^{-2} \mathrm{~d}^{-1}$} \\
\hline I & $95 \mathrm{a}$ & $208 \mathrm{~b}$ & $38 \mathrm{a}$ & $53 \mathrm{a}$ & $4.4 \mathrm{~b}$ & $5.2 \mathrm{a}$ \\
\hline II & $144 \mathrm{a}$ & $239 \mathrm{ab}$ & $44 \mathrm{a}$ & $44 \mathrm{ab}$ & $5.5 \mathrm{ab}$ & $4.9 \mathrm{a}$ \\
\hline III & $145 \mathrm{a}$ & $225 \mathrm{ab}$ & $49 \mathrm{a}$ & $39 \mathrm{~b}$ & $6.4 \mathrm{a}$ & $4.5 \mathrm{a}$ \\
\hline IV & $123 \mathrm{a}$ & $267 \mathrm{a}$ & $49 \mathrm{a}$ & $47 \mathrm{ab}$ & $6.4 \mathrm{a}$ & $5.7 \mathrm{a}$ \\
\hline Mean & 130 & $233^{(1)}$ & 45 & 45 & 5.6 & 5.0 \\
\hline
\end{tabular}

${ }^{(1)}$ Significant difference between $\mathrm{P}$ level by $\mathrm{F}$ test at $0.1 \%$ level. Means followed by the same letter within a column do not differ by Tukey test $5 \%$.

Plant dry mass and leaf area of bean genotypes were highly correlated at both $\mathrm{P}$ level at pod setting (Figure 2), and also at early pod filling $(\mathrm{r}=0.90$ and 0.77 at low and high $\mathrm{P}$ level, respectively). At pod setting, leaf area correlated with leaf mass at both $\mathrm{P}$ level (Figure 2). Leaf area correlated with the number of leaves at high $\mathrm{P}$ level but not at low $\mathrm{P}$ level. Otherwise, leaf area correlated with leaf size at low $\mathrm{P}$ but not at high $\mathrm{P}$ level. Leaf area correlated positively with specific leaf area at low $\mathrm{P}$ level but negatively at high $\mathrm{P}$ level. Leaf size was highly and positively correlated with specific leaf area (Figure 2), genotypes with greater leaves showing thinner leaves such as group I (Table 2). Hence, the general pattern that larger leaves of a given species tend to have lower specific leaf area due to a relatively high investment in support and transport tissues (Milla et al., 2008) did not hold among common bean genotypes. These correlation patterns were almost the same at early pod filling, except for the non-significant correlation between leaf area and specific leaf area at both $\mathrm{P}$ level.

Multiple regression showed that at low $\mathrm{P}$ level most variation among genotypes for plant dry mass was accounted for by variations in leaf size, whereas at high $\mathrm{P}$ level the variation of plant mass was primarily associated with the number of leaves and secondarily with leaf size, either at pod setting or at early pod filling (Table 4). At early pod filling, the proportion of mass allocated into leaves explained part of the variation of plant mass at both $\mathrm{P}$ level. The specific leaf area played a minor role on genotypic variation of total mass at both $\mathrm{P}$ level and growth stages (Table 4). 

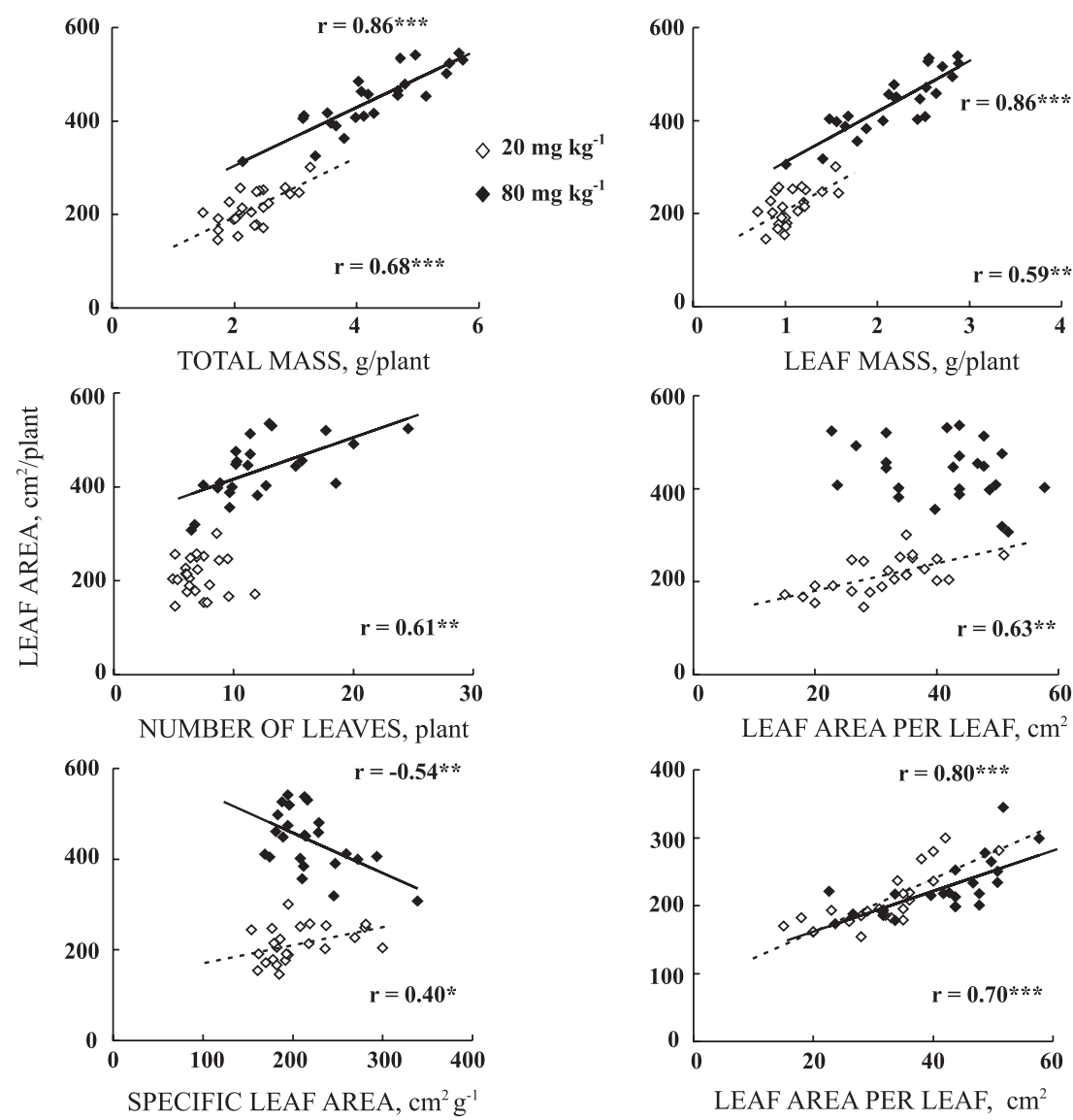

Figure 2. Simple correlation between leaf traits of 24 common bean genotypes grown at $P$ level applied to the soil of $20(\square)$ and $80(\square) \mathrm{mg} \mathrm{kg}^{-1}$ of $P$, at the stage of pod setting; squares represent experimental means of four replicates, and lines represent the simple linear regression. *, **, ***: correlation coefficient significant at the 5,1 and $0.1 \%$ levels by t test. Correlation patterns were the same at early pod filling, except for the non-significant correlation between leaf area and specific leaf area at both $P$ level $(r<0.21)$.

Table 4. Models of stepwise multiple regression analysis, considering total plant dry mass as dependent variable and leaf traits as independent variables, for 24 common bean genotypes grown at two $P$ level applied to the soil (20 and $80 \mathrm{mg} \mathrm{kg}^{-1}$ of P) at two growth stages (pod setting and early pod filling)

\begin{tabular}{|c|c|c|c|c|c|c|c|c|}
\hline \multirow{2}{*}{ Plant trait } & \multicolumn{2}{|c|}{ Pod setting } & \multicolumn{2}{|c|}{ Pod setting } & \multicolumn{2}{|c|}{ Early pod filling } & \multicolumn{2}{|c|}{ Early pod filling } \\
\hline & Isolated effect & $\mathrm{R}^{2}$ & Isolated effect & $\overline{\mathrm{R}^{2}}$ & Isolated effect & $\mathbf{R}^{2}$ & Isolated effect & $\overline{\mathbf{R}^{2}}$ \\
\hline & $20 \mathrm{mg} \mathrm{kg}^{-1}$ & & $80 \mathrm{mg} \mathrm{kg}^{-1}$ & & $20 \mathrm{mg} \mathrm{kg}^{-1}$ & & $80 \mathrm{mg} \mathrm{kg}^{-1}$ & \\
\hline Number of leaves & 1.405 & 0.241 & 4.408 & 0.560 & 0.367 & 0.073 & 1.590 & 0.421 \\
\hline Leaf area per leaf & 2.218 & 0.622 & 1.819 & 0.792 & 3.434 & 0.754 & 0.857 & 0.648 \\
\hline Specific leaf area & 1.090 & 0.810 & 1.056 & 0.926 & 0.225 & 0.799 & 0.218 & 0.706 \\
\hline Lea f mass ratio & 0.963 & 1.000 & 0.585 & 1.000 & 1.016 & 1.000 & 1.113 & 1.000 \\
\hline
\end{tabular}

Model: $\ln \mathrm{M}_{\mathrm{T}}=\ln \mathrm{N}_{\mathrm{L}}+\ln \mathrm{A}_{\mathrm{L}} / \mathrm{N}_{\mathrm{L}}-\ln \mathrm{SLA}-\ln \mathrm{LMR}$, where $\mathrm{M}_{\mathrm{T}}$ is the total plant dry mass, $\mathrm{N}_{\mathrm{L}}$ the number of leaves per plant, $\mathrm{A}_{\mathrm{L}} /$ $\mathrm{N}_{\mathrm{L}}$ the leaf area per leaf, SLA the specific leaf area $\left(\mathrm{A}_{\mathrm{L}} / \mathrm{M}_{\mathrm{L}}\right)$, and LMR the leaf mass ratio $\left(\mathrm{M}_{\mathrm{L}} / \mathrm{M}_{\mathrm{T}}\right)$.

\section{DISCUSSION}

Leaf traits of common bean genotypes in the beginning of the reproductive stage are described herein, of individual plants grown in pots in open-air at plentiful luminosity under limited and adequate levels of soil P supply. Actually, the responses of leaf traits reported here comprise two sources of variation (as pointed out by Milla et al., 2008): the genetic differences between distinct genotypes and the 
phenotypic plasticity in response to different levels of soil P supply. Genotypes were also grouped according to their growth habit, aiming to identify some relations between shoot architecture and leaf area growth.

\section{Phosphorus response}

The specific leaf area was assessed as the ratio between the whole leaf area and leaf dry mass of one plant, thus including leaves of different ages. Relationships between total leaf area and specific leaf area were complex (Figure 2). Broadly, at low P level genotypes with larger leaf area at pod setting presented higher specific leaf area as in groups I and II, whereas at high $\mathrm{P}$ level the larger leaf area was associated with lower specific leaf area as in groups III and IV (Figure 2 and Table 2). These relationships did not hold at early pod filling. A small portion of the variation among genotypes for plant mass was ascribed to specific leaf area (Table 4), confirming that specific leaf area is a component of minor relevance for determining plant growth under conditions of high irradiance (Shipley, 2006). Specific leaf area reflects a strategy of resource allocation within an individual leaf, reacting markedly to changes in internal or external inputs suffered by the plant during its lifespan (Milla et al., 2008). For this reason, specific leaf area of bean plants usually presents strong environmental and ontogenetic variations (White \& Montes-R., 2005), as well as marked interactions with P supply (Araújo et al., 1998), which could lessen the usefulness of specific leaf area as a selection criterion for low-P tolerance.

The high soil $\mathrm{P}$ level doubled the leaf area of bean plants at pod setting and early pod filling, this augment is obtained mainly by increasing the number of leaves and in a lesser extent the leaf area per leaf (Table 2). A wide range of $\mathrm{P}$ status did not affect the stage in which bean plants attained their maximal leaf number, but plants at high $\mathrm{P}$ supply had more leaves than those at limited P, although plants at high $\mathrm{P}$ had also advanced the stage of maximal leaf abscission (Araújo et al., 2007). This confirms that leaf area of bean plants responds to increased $\mathrm{P}$ supply mainly by improving leaf appearance and secondarily by enhancing leaf expansion (Lynch et al., 1991).

\section{Genotypic variability}

Grouping genotypes according to their growth habit provided insights on the nature of genotypic variability of leaf traits in common bean, inasmuch as each growth habit showed different strategies for producing leaf area. Genotypes of habit I presented lower overall leaf area, fewer but larger leaves with higher SLA, and lower NAR (Tables 2 and 3). These genotypes did not increase the leaf area between pod setting and early pod filling at low P level (Table 2), in part due to the abscission of their large primary leaves, exhibiting feeble tolerance to limited P supply. Even lacking a precise genetic background of some evaluated genotypes, the cultivars of group I are supposed to pertain to Andean origin, based on their leaf traits and large seed (Table 1; Singh, 2001), confirming the photosynthetic characteristics reported by González et al. (1995) and Sexton et al. (1997). For crop areas where earliness is desirable, bush determinate cultivars can be sown at high densities also for mechanical harvesting, partially compensating for their lower leaf area per plant, but because of the short growth duration their yield potential is usually not very large (Laing et al., 1984).

Genotypes of habits II and III, which share the degree of determinacy but differ in stem uprightness, showed similar leaf traits. They presented the largest leaf area at both $\mathrm{P}$ level and both harvests, achieved through intermediate number of leaves, leaf size and SLA, in comparison with the other groups (Table 2). Groups II and III also had the highest root growth, combined with large shoot yield at low $\mathrm{P}$ level at early pod filling (Table 2), showing an overall better adaptation to limited $\mathrm{P}$ supply. For environments in which there is an adequate water supply, genotypes of habit II that did not lodge are usually recommended, their upright stems also allowing for mechanical harvesting (Laing et al., 1984; Singh, 2001). Yet in drier areas or subsistence farming, plants of habit III are preferred because their branching and prostrate habit permits compensation for low planting density or drought (Graham \& Ranalli, 1997).

Climbing plants of habit IV, that included two weedy genotypes, showed the greatest number of leaves, combined with smaller and thicker leaves with higher NAR (Tables 2 and 3). These plants responded markedly to increased $\mathrm{P}$ supply: at both growth stages, the shoot dry mass and leaf area more than doubled as P level was raised (Table 2). Moreover, they presented the smallest root growth at low P level, denoting a weak adaptation to limited $\mathrm{P}$ supply. The poor performance of wild genotypes of $P$. vulgaris under limited-P conditions was reported by Araújo et al. (1997) and Beebe et al. (1997), indicating that common bean adaptation to low $\mathrm{P}$ soils has been improved during domestication. However, concerning the evidence that habit IV is the most genetically variable among common bean germplasm (Beebe et al., 1997), the small evaluated sample hinders more extensive conclusions about this group.

The overall growth and the production of leaf area of bean plants at reproductive stages were strictly associated (Figure 2). The similar slope of the regression lines of total dry mass on leaf area at both $P$ level (Figure 2) indicates that any increase in biomass requires a correspondent increase in leaf area irrespective of the soil P supply. It suggests that the selection of bean lines more tolerant to low $\mathrm{P}$ soils will require plants able to maintain adequate leaf growth during pod filling. At low $\mathrm{P}$ supply, leaf area was correlated with leaf size and specific leaf area at 
early pod filling (Figure 2), and leaf size accounted for most variation in total mass at both growth stages (Table 4). Even discarding the genotypes of group I, which presented larger leaves and high leaf area at pod setting at low $\mathrm{P}$ (Table 2) due to their large primary leaves associated with high seed reserves (Table 1), the correlation between leaf area and leaf size at low $\mathrm{P}$ remained high $(\mathrm{r}>0.61, \mathrm{p}<0.01$ at both growth stages). This indicates that improved leaf growth at low $\mathrm{P}$ would be achieved by genotypes with greater leaf size, thus by genotypes able to maintain the expansion of individual leaves at limited $\mathrm{P}$ supply during reproductive stages.

In soybean plants deprived of $\mathrm{P}$, decreases in leaf area were observed before the rate of photosynthesis per leaf area was affected, and low P supply markedly increased the starch contents of young leaves, suggesting that leaf growth was not limited by the carbohydrate supply (Fredeen et al., 1989). It is hypothesized that the restricted rate of expansion of individual leaves could result from reduced leaf epidermal cell area (Fredeen et al., 1989), fewer cells per leaf primordia or limited cell elongation (Rodríguez et al., 1998). More detailed studies could assess modifications in leaf morphology of bean genotypes induced by distinct $\mathrm{P}$ status, in order to identify leaf characteristics liable to maintain leaf expansion at low P supply. Such investigations should prioritize plants of growth habits II and III as source of tolerance of leaf growth to limited $\mathrm{P}$ supply.

\section{CONCLUSIONS}

At low soil P level, the leaf area of bean genotypes correlates with leaf size, and leaf size accounts for most genetic variation in total plant biomass, which indicates that improved growth at low $\mathrm{P}$ would be achieved by genotypes able to maintain leaf expansion during pod filling through leaves with greater individual leaf area. Erect indeterminate and prostrate indeterminate genotypes seem more promising as a source of tolerance to low $\mathrm{P}$ soils regarding with leaf area growth.

\section{LITERATURE CITED}

ARAÚJO, A.P.; KUBOTA, F.Y. \& TEIXEIRA, M.G. Leaf senescence of common bean plants as affected by soil phosphorus supply. R. Bras. Ci. Solo, 31:501-508, 2007.

ARAÚJO, A.P. \& TEIXEIRA, M.G. Ontogenetic variations on absorption and utilization of phosphorus in common bean cultivars under biological nitrogen fixation. Plant Soil, $225: 1-10,2000$.

ARAÚJO, A.P. \& TEIXEIRA, M.G. Relationships between grain yield and accumulation of biomass, nitrogen and phosphorus in common bean cultivars. R. Bras. Ci. Solo, 32:1977-1986, 2008
ARAÚJO, A.P.; TEIXEIRA, M.G. \& ALMEIDA, D.L. Phosphorus efficiency of wild and cultivated genotypes of common bean (Phaseolus vulgaris L.) under biological nitrogen fixation. Soil Biol. Biochem., 29:951-957, 1997.

ARAÚJO, A.P.; TEIXEIRA, M.G. \& ALMEIDA, D.L. Variability of traits associated with phosphorus efficiency in wild and cultivated genotypes of common bean. Plant Soil, 203:173-182, 1998 .

BEEBE, S.; LYNCH, J.; GALWEY, N.; TOHME, J. \& OCHOA, I. A geographical approach to identify phosphorusefficient genotypes among landraces and wild ancestors of common bean. Euphytica, 95:325-336, 1997.

CHACÓN S., M.I.; PICKERSGILL, B. \& DEBOUCK, D.G. Domestication patterns in common bean (Phaseolus vulgaris L.) and the origin of the Mesoamerican and Andean cultivated races. Theor. Appl. Genet., 110:432444,2005

FREDEEN, A.L.; RAO, I.M. \& TERRY, N. Influence of phosphorus nutrition on growth and carbon partitioning in Glycine max. Plant Physiol., 89:225-230, 1989.

GEPTS, P.; OSBORN, T.C.; RASHKA, K. \& BLISS, F.A. Phaseolin-protein variability in wild forms and landraces of the common bean (Phaseolus vulgaris): Evidence for multiple centers of domestication. Econ. Bot., 40:451-468, 1986.

GONZÁLEZ, A.; LYNCH, J.; TOHME, J.M.; BEEBE, S.E. \& MACCHIAVELLI, R.E. Characters related to leaf photosynthesis in wild populations and landraces of common bean. Crop Sci., 35:1468-1476, 1995.

GRAHAM, P.H. \& RANALLI, P. Common bean (Phaseolus vulgaris L.). Field Crops Res., 53:131-146, 1997.

KONDRACKA, A. \& RYCHTER, A.M. The role of $\mathrm{P}_{\mathrm{i}}$ recycling processes during photosynthesis in phosphate-deficient bean plants. J. Exper. Bot., 48:1461-1468, 1997.

LAING, D.R.; JONES, P.G. \& DAVIS, J.H.C. Common bean (Phaseolus vulgaris L.). In: GOLDSWORTHY, P.R. \& FISHER, N.M., eds. The physiology of tropical field crops. New York, John Wiley, 1984. p.305-351.

LIMA, E.R.; SANTIAGO, A.S.; ARAÚJO, A.P. \& TEIXEIRA, M.G. Effects of the size of sown seed on growth and yield of common bean cultivars of different seed sizes. Braz. J. Plant Physiol., 17:273-281, 2005.

LYNCH, J.; LÄUCHLI, A. \& EPSTEIN, E. Vegetative growth of the common bean in response to phosphorus nutrition. Crop Sci., 31:380-387, 1991.

LYNCH, J. \& RODRIGUEZ H., N.S. Photosynthetic nitrogenuse efficiency in relation to leaf longevity in common bean. Crop Sci., 34:1284-1290, 1994

MILLA, R.; REICH, P.B.; NIINEMETS, Ü. \& CASTRO-DÍEZ, P. Environmental and developmental controls on specific leaf area are little modified by leaf allometry. Funct. Ecol., 22:565-576, 2008.

NETER, J.; WASSERMAN, W. \& KUTNER, M.H. Applied linear statistical models. 3.ed. Burr Ridge, Richard D. Irwin, 1990. 1181p. 
RICHARDS, R.A. Selectable traits to increase crop photosynthesis and yield of grain crops. J. Exper. Bot., 51:447-458, 2000.

RODRÍGUEZ, D.; KELTJENS, W.G. \& GOUDRIAAN, J. Plant leaf area expansion and assimilate production in wheat (Triticum aestivum L.) growing under low phosphorus conditions. Plant Soil, 200:227-240, 1998.

SANTOS, M.G.; RIBEIRO, R.V.; OLIVEIRA, R.F. \& PIMENTEL, C. Gas exchange and yield response to foliar phosphorus application in Phaseolus vulgaris L. under drought. Braz. J. Plant Physiol., 16:171-179, 2004.

SEXTON, P.J.; PETERSON, C.M.; BOOTE, K.J. \& WHITE, J.W. Early-season growth in relation to region of domestication, seed size, and leaf traits in common bean. Field Crops Res., 52:69-78, 1997.

SEXTON, P.J.; WhiTE, J.W. \& BoOTE, K.J. Yielddetermining processes in relation to cultivar seed size of common bean. Crop Sci., 34:84-91, 1994.
SHIPLEY, B. Net assimilation rate, specific leaf area and leaf mass ratio: Which is most closely correlated with relative growth rate? A meta-analysis. Funct. Ecol., 20:565-574, 2006.

SINGH, S.P. Broadening the genetic base of common bean cultivars: A review. Crop Sci., 41:1659-1675, 2001.

STONE, L.F. \& PEREIRA, A.L. Sucessão arroz-feijão irrigados por aspersão: Efeitos de espaçamento entre linhas, adubação e cultivar no crescimento, desenvolvimento radicular e consumo d'água do feijoeiro. Pesq. Agropec. Bras., 29:939-954, 1994.

WALLACE, D.H.; OZBUN, J.L. \& MUNGER, H.M. Physiological genetics of crop yield. Adv. Agron., 24:97146, 1972

WHITE, J.W. \& MONTES-R., C. Variation in parameters related to leaf thickness in common bean (Phaseolus vulgaris L.). Field Crops Res., 91:7-21, 2005. 